\title{
LA REVISTA ALDABA, UN NUEVO NÚMERO Y UN ANTIGUO COMPROMISO
}

\author{
Antonio Bravo Nieto \\ Director de la Revista Aldaba \\ Director del Centro UNED Melilla
}

Asumir empresas que ya tienen un amplio recorrido y continuar trabajando en sus valores más universales y destacados, es un reto lo suficientemente sugerente como para aceptarlo sin reservas. Y este reto de la revista Aldaba, en su cuadragésimo número, nos permite recordar toda su trayectoria y al mismo tiempo poder agradecer a las personas que durante toda su vida editorial han conseguido elevarla al nivel académico y científico que hoy día tiene. Y decir Aldaba, sin duda, es nombrar a José Megías Aznar, que ha sido su creador y director, la persona que durante 33 años ha conseguido crear y consolidar una prestigiosa revista, y sobre todo una forma de entender el trabajo en equipo, haciendo partícipe en sus números a muchos colaboradores que se pudieron expresar en sus páginas científica y académicamente, entre los que he tenido el honor de estar desde hace ya muchos años. También es de justicia recordar al que fuera director del Centro, Ramón Gavilán Aragón, que supo crear bajo su dirección las condiciones para que la revista naciera y pudiera engrandecerse año tras año.

Este número cuarenta es un número especial, porque el centro UNED Melilla cumple cuarenta años, y por eso contamos de forma especial y destacada con las presentaciones que nos han redactado el Rector de la UNED, Alejandro Tiana Ferrer y el Presidente de la Ciudad Autónoma de Melilla y Presidente del Consejo Rector UNED Melilla, Juan José Imbroda Ortiz. Una conjunción que refleja perfectamente nuestro espíritu, la forma en la que UNED y Ciudad confluyen en objetivos comunes por el bien de su sociedad.

Un primer corpus de artículos relacionados con el Centro UNED Melilla se inicia con un trabajo sobre la propia revista, que sirve también de re- 
flexión sobre sus números anteriores y su trayectoria: "Aldaba (1983-2016). Una revista pluridisciplinar con un especial interés por Melilla y su entorno”, que ha escrito acertadamente José Megías Aznar. Por su parte, Blas Jesús Imbroda Ortiz, profesor tutor de Derecho Penal del Centro UNED Melilla y Decano del Colegio de Abogados de esta ciudad nos habla en su artículo sobre el importante papel que la UNED ha desempeñado en la formación de los abogados que ejercen en la ciudad y sobre su trayectoria profesional.

Un segundo bloque engloba varios trabajos centrados en los estudios sobre la Historia, Ciencias Sociales y Humanidades de Melilla y su entorno. Se abre con un trabajo de Manuel Aragón Gómez, profesor tutor de Historia Antigua Universal del Centro UNED Melilla sobre "Sifax, el rey númida Masaesilio en los pasajes de Tito Livio”, y por su parte Isabel Mª Migallón Aguilar, licenciada en Geografía e Historia UNED, escribe un trabajo sobre la sociedad de la ciudad en el siglo XVIII: "La población de Melilla en 1756. Ratificación de la Virgen de la Victoria como Patrona”. En el campo de la historia de la geología José Luis Barrera Morate, de la International Commision on the History of Geological Sciences (INHIGEO), esboza una interesante biografía: "Lucas Fernández Navarro. El primer geólogo español que pisó las islas Chafarinas”. Finalmente, Francisco Narváez López, profesor tutor de Derecho Internacional Público del Centro UNED Melilla estudia en su trabajo los "Orígenes del topónimo Río de Oro”.

Un tercer bloque temático reúne una serie de trabajos sobre el norte de África, Iberoamérica y Filipinas, y es el que refleja de una forma más evidente el carácter internacional de la revista. Juan Corbalán de Celis y Durán, académico correspondiente de la Real Academia de Cultura Valenciana aborda un trabajo sobre la intervención americana del que llegaría a ser gobernador de Melilla: "Los servicios del capitán Miguel de Perea en la armada de guarda de la flota de Indias”. La profesora Emilie D’Orgeix, maitre de conférences en histoire de l'art Université Bordeaux-Montaigne aporta nuevas perspectivas sobre el trabajo de los ingenieros militares en las ciudades francesas en América : "Quelques considérations sur les traceurs de plans dans l'Amérique coloniale aux XVII et XVIII siècles: l'exemple des fondations urbaines en Nouvelle-France”. En otro continente, pero abordando temas similares, Pedro Luengo, profesor de la Universidad de Sevilla y del King's College London 
aborda las "Fortificaciones musulmanas en Joló: Resistencia, adaptación y reinterpretación de la guerra moderna occidental”. Desde el punto de vista de la arquitectura islámica sufí, Jaime Vergara Muñoz, doctor arquitecto y Miguel Martínez Monedero, doctor arquitecto de la Universidad de Granada, aportan un análisis sobre "La zagüía Sidi Ali Ben Handuch de la Medina de Arcila (Marruecos)”. El último trabajo de este bloque está escrito por Claudio Verdugo, arquitecto, miembro de la Unión Internacional de Arquitectos y antiguo profesor de la Escuela de Arquitectura de Rabat, que asume en su trabajo la difícil pero apasionante tarea de repasar su dilatada biografía profesional.

Para terminar este número de Aldaba, Sonia Gámez Gómez, profesora tutora de Métodos y Técnicas de Investigación Histórica del Centro UNED Melilla y coordinadora del COIE, realiza un índice general de los cuarenta números de la revista, tanto cronológico como de autores, que sirve de herramienta para acceder a toda la información que en ella se contiene, y al mismo tiempo nos ha permitido reflexionar sobre la propia revista.

Esperamos que este número, como reflejo de la capacidad de toda su comunidad educativa, sea un sillar más de este edificio editorial que ha permitido y permite crecer tanto a la UNED como a la ciudad de Melilla. 